\title{
WATER BUDGETS AS A TOOL FOR LANDFILL OWNERS AND DECISION MAKERS
}

\author{
William Hogland ${ }^{l}$ \\ Lars Thörneby ${ }^{l}$ \\ Lennart Mathiasson ${ }^{2}$ \\ Lennart Mårtensson ${ }^{3}$ \\ ${ }^{I}$ University of Kalmar, Sweden \\ ${ }^{2}$ University of Lund, Sweden \\ ${ }^{3}$ University of Kristianstad, Sweden
}

\begin{abstract}
According to the outcome of a United Nations conference in Johannesburg, 2002, many countries of the world are facing large water management challenges that require groundwater and surface water resources to be protected. Leachate from landfills and city dumps is a significant source of groundwater and surface water contamination. Local Environmental Protection Authorities have, during recent years, increased their requirements on the municipalities, the waste management companies and the industries that are running solid waste landfills. These requirements include having a good knowledge of and control over the water budget and the geohydrological position of the landfill area and its surroundings. In the case of new landfills, the demands are higher. According to the Waste Council Directive 1999/31/EC on landfilling of waste, the Member States should set up a national strategy for pollution reduction, water control and leachate management at landfill areas. A meteorological station should be located on site. In order to ensure a proper and optimized design of the facilities, it is of the highest importance to know the seasonal and short-time variations of the different terms of the water balance, from both a quantitative and a qualitative point of view. Water budgets for an entire area can give a picture of water conservation, water allocation priorities, groundwater and stream flow, pollution tracking and ecosystem requirements in the whole region around the landfill. These budgets can easily be made as hand calculations. In order to ensure adequate designs that are practical and economical, it is essential to have reliable and accurate design tools and models available to estimate the water balance components and to predict liquid movement into, through, and out of landfills of various designs. There are a number of models, such as HELP, PREFLO, MOBYDEC and FILL, available. However, this paper presents water budget calculations on various time bases that can easily be carried out by hand and by the landfill owner.
\end{abstract}




\section{INTRODUCTION}

The majority of the landfills in the world are badly located and must be considered to be a threat, from the environmental point of view, to the quality of air, land and waters. Air pollution caused by landfills is dominated by landfill gas emission, of which the methane component (rather than carbon dioxide) is the more serious due to its greater greenhouse effect, but landfill fires and open burning of solid waste are other sources of pollution. Litter can also be spread by the wind if the waste is not covered directly after tipping or it might drop from the garbage trucks during transportation if proper vehicles are not used. Water is affected when dumping is directly at riverbanks, in marshlands, or directly into the sea. Old landfills and dumpsites usually affect ground and surface waters because they have not been located with regard to geohydrological considerations, have not been properly equipped with final coverage, or are not constructed with a bottom liner and leachate collection systems.

In the European Union, a modern landfill should be constructed according to Waste Council Directive 1999/31/EC on landfilling of waste. The Member States should set up a national strategy for pollution reduction, water control and leachate management at the landfill area. A meteorological station should be located on site. In order create proper and optimized design of the facilities, it is of highest importance to know the seasonal and short-time variations of the different terms of the water balance as well as the geohydrological situation, both from quantitative and qualitative point of view, at the landfill site and the areas where the local treatment systems will be or are constructed. By first order estimations and discussions with local environmental authorities, the seasonal and short-term variations of the different terms of the water balance situation, both quantitative and qualitative, can easily be estimated by hand. Even those landfill owners and waste management companies operating landfills that are following the EU-directive do not always consider the geohydrological situation in the area when designing leachate treatment systems and locate them offsite. In order to design proper and optimized facilities, it is of the highest importance to have detailed knowledge of the water situation in the area at different times. There are a variety of computer-based models such as HELP (Schroeder et al., 1994) PREFLO model (Ugoccioni and Zeiss, 1997), MOBYDEC model (Guyonn et al., 1998), FILL that can be used for detailed modelling of the landfill site and its leachate treatments systems.

The General Assembly of the United Nations adopted its resolution 58/217 proclaiming an International Decade for Action, "Water for Life", 2005-2015, to commence on World Water Day, 22 March 2005. The goals will be focused on water-related issues at all levels and on implementation of programmes and projects and furtherance of cooperation at all levels. This is in order to emphasis the achievement of the internationally agreed water-related goals in the United Nations Millennium Declaration, in Agenda 21, and in the Johannesburg Plan of Implementation; the World Summit of Sustainable Development of August 2002. The goal is to halve, by the year 2015, the number of people who are unable to reach or to afford safe drinking water as well as the proportion of people without access to basic sanitation. Proper landfilling and leachate treatment can contribute significantly to the protection of surface and ground waters and reduce the degradation of world freshwater sources. 


\subsection{The water budget}

The precipitation falling on the landfill or leachate treatment system as rain, snow or hail either runs off the ground surface, is taken up by the vegetation or, if the landfill is not covered, is absorbed into the waste. If the landfill is not properly covered, part of the precipitation that infiltrates into the landfill percolates further through the waste and generates leachate. The leachate might reach the groundwater table or surface water near by if it is not collected and treated. Evapotranspiration is usually calculated with Thornthwaite's or Penman's equation. Measurements on site with different types of evaporations pans, evapotranspirometers or lysimeters are also possible. Evaporation depends on the ambient temperature, wind speed, differences in vapour pressure between surfaces where evaporation takes place, and the air pressure. These parameters should be measured locally since they vary with the local climatic conditions. Estimations of runoff in the form of stormwater (Marques and Hogland, 2003b) and/or leachate can be made by means of direct measurements in the field or by theoretical calculations. Stormwater at landfill sites is generated at waste sorting areas and roads. A greater amount is produced at modern landfill sites and it must be handled properly. Peak runoff flows can be estimated by the rational method and the degree-day method can be used to estimate snow melt. The daily leachate generation at the landfill site can be estimated either by the mean of the inflow and outflow according to calculations obtained with the water balance method or by using the values observed by field measurements. The delay of the runoff is, of course, always best observed by inflow and outflow control. A test area can be established on the landfill site or offsite at the local leachate treatment site. On the basis of the values for leachate production measured in the test area, or possibly from another landfill site with similar conditions, the volume of leachate from the landfill can be estimated empirically.

The water balance in its simplest form is described as:

$L v=P-E T_{L}-R o-\Delta S$

where $\Delta S$ is zero when calculated for the hydrological year.

In a more detailed form the water balance can be written as:

$$
P+R_{I N}+G_{I N}+W_{I N}=E T_{L}+L_{R}+L_{G}+L S+R o+\Delta S+\Delta W+\Delta B+\Delta S_{n}
$$

where $P$ is precipitation, $R_{I N}$ is the inflow of surface water, $G_{I N}$ is the inflow of groundwater, $\mathrm{Wi}$ is water contained within the waste, $\mathrm{ET}_{\mathrm{L}}$ is water removal by evaporation and transpiration (ET), Lv is leachate generated after installation of a final cover (e.g., $L_{R}+L_{G}$ ), $L_{R}$ is collected leachate, $L_{G}$ is leakage of leachate to groundwater, $\mathrm{L}_{S}$ is collected stormwater from roads and sorting areas, Ro is outflow of surface water; $\Delta \mathrm{S}$ is the change in storage of water in cover soil, $\Delta \mathrm{W}$ is change in storage of water in the waste, $\Delta \mathrm{B}$ is change in metabolic water (bacterial production and consumption), and $\Delta \mathrm{S}_{\mathrm{n}}$ 
KALMAR ECO-TECH'03

Bioremediation and Leachate Treatment

KALMAR, SWEDEN, November 25-27, 2003

is snow storage. In Figure 2, a rough water budget calculation is given on an annual basis for the Moskogen landfill, located in the south-eastern part of Sweden.

\subsection{The Moskogen landfill}

The Moskogen landfill is located in the Ljungby River catchment, which is a typical small river basin system for this part of Sweden. The landfill receives 40,000 tonnes of solid waste annually from three communities, with a total population of 90,000 , although the municipality of Kalmar is the predominant source of waste. The annual precipitation in the area varies between $296-782 \mathrm{~mm}$, with a 30-year average of $470 \mathrm{~mm}$ (Normal 1931-60, SMHI), there are 93 days per annum with precipitation higher than $1 \mathrm{~mm}$ and the average temperature is $6.8^{\circ} \mathrm{C}$. The drained landfill area is in total 29 ha, of which 22 ha is under preliminary cover and 7 ha is in operation. Annually, about $150,000 \mathrm{~m}^{3}$ leachate is produced, of which almost $85,000 \mathrm{~m}^{3}$ is groundwater inflow via the northwestern part of the landfill. Before 1998, the production of leachate was $100,000 \mathrm{~m}^{3} / \mathrm{yr}$, which was treated in a plant system (SP) in combination with three ponds of size 1.5 ha (volume 30,000 $\mathrm{mt}^{3}$ ), 2.7 ha (volume $45,000 \mathrm{mt}^{3}$ ) and 2.6 ha (volume $50,000 \mathrm{~m}^{3}$ ) respectively. Former agricultural land located outside the south-eastern corner of the landfill is planted with willow (Salix spp.), 10 ha in total. A part (4 ha) of the old landfill is planted with energy grass (Phalaris arundinacea), which is irrigated with leachate. However, about $70,000 \mathrm{~m}^{3}$ of the leachate is still pumped to the wastewater treatment plant in the city of Kalmar.

The evaporation from the ponds and the irrigation onto the landfill site (energy grass area) has been estimated to about $60,000 \mathrm{~m}^{3}$ per annum. An amount of $50,000 \mathrm{mt}^{3}-$ $100,000 \mathrm{~m}^{3}$ goes to the area with Salix forest (the Salix area). The collected drain water from the Salix area is about $100,000 \mathrm{mt}^{3}$ of which $70,000 \mathrm{~m}^{3}$ goes to the municipal wastewater treatment plant in Kalmar and the rest, $30,000 \mathrm{~m}^{3}$ is pumped back to pond D2 (see Figure 1). Irrigation of energy forest or land surfaces increases the possibility of natural evaporation. When an area of the landfill is irrigated, the water balance will change. The evapotranspiration will then be close to or above the potential evapotranspiration and thus it is possible to use the difference between precipitation and evapotranspiration for water removal during the period April-September in southern Sweden.

"How clean is clean" is the question that is raised about the water that leaves the drainage pipe underneath the Salix plantation. Some assert that, once the water is classified as leachate, it keeps its label even after advanced treatment has produced a quality close to drinking water standards for most parameters. Is it then possible to discharge such water in an environmentally acceptable way outside the landfill? One option at the Moskogen landfill could be to discharge the drainage from the irrigation area into the Tomtebybäcken, a rivulet (grass covered ditch) that, after about $7 \mathrm{~km}$, joins the Ljungby River $1.5 \mathrm{~km}$ east of the village Ljungbyholm. In Figure 1, a preliminary water balance for the landfill and the treatment system is given. In the calculation it is assumed that $8,000 \mathrm{mt}^{3}$ of water is absorbed by the incoming waste before reaching field capacity. Water flows in the filling phase of a landfill has been studied by Marques and Hogland (2003a). 
KALMAR ECO-TECH'03

Bioremediation and Leachate Treatment

KALMAR, SWEDEN, November 25-27, 2003

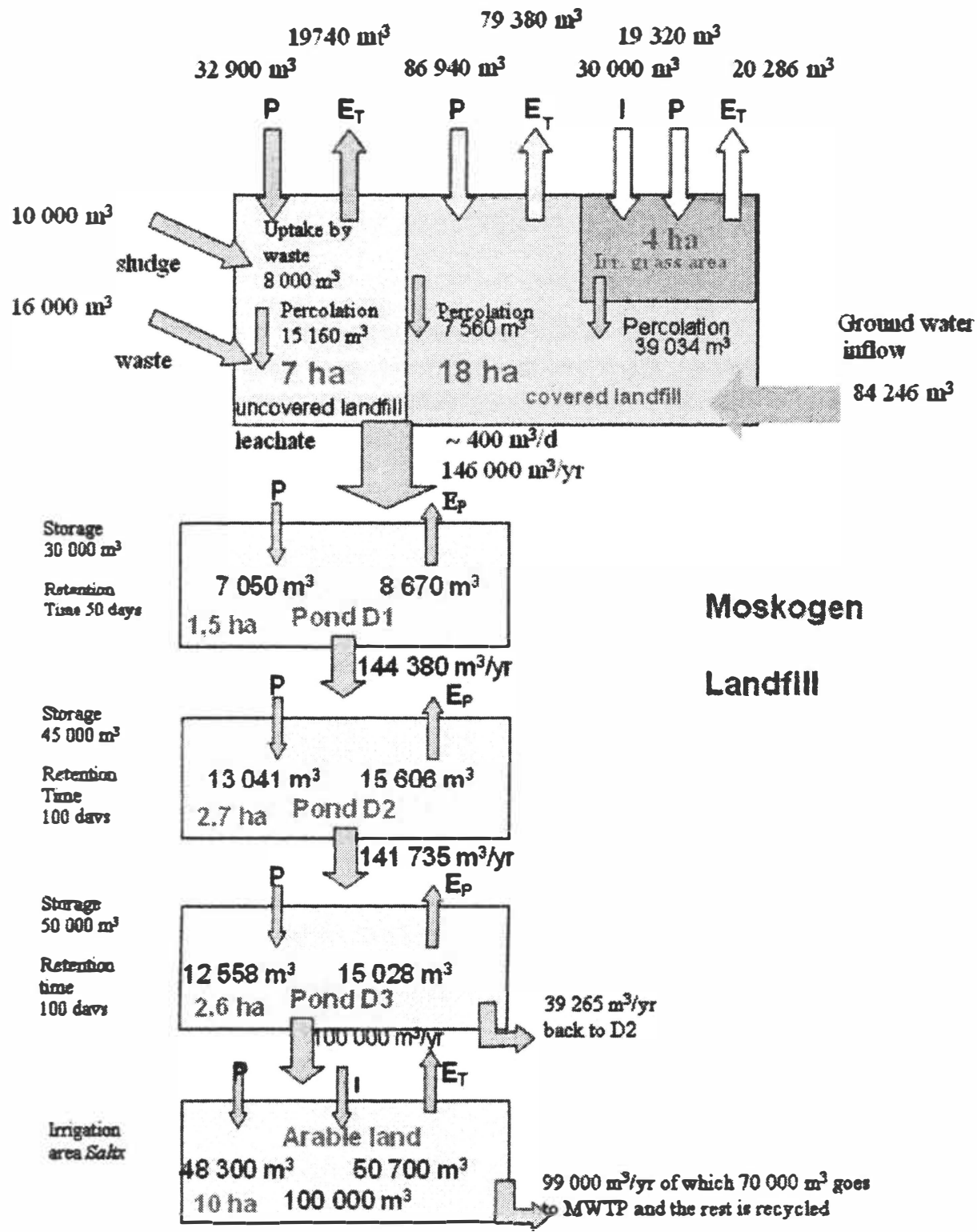

Figure 1. Preliminary water budget for the Moskogen landfill, Sweden (Hogland et al., 2003) 
KALMAR ECO-TECH'03

Bioremediation and Leachate Treatment

KALMAR, SWEDEN, November 25-27, 2003

Figure 1. Preliminary water budget for the Moskogen landfill, Sweden (Hogland et al., 2003)

Similar water budgets can be constructed for each month of the year, single weeks and for special rainfall events or snow melts. The water budgets are established for the winter month of December, when no irrigation occurs, evapotranspiration is very low and the groundwater table is close to its maximum level. It has been found that at this time, about $4,800 \mathrm{mt}^{3}$ of precipitation falls over the energy grass and the Salix area together, about $1500 \mathrm{~m}^{3}$ is transpired by vegetation, and the ponds are filling up because of groundwater inflow and leachate production. During the summer month of August, the precipitation over the two irrigation areas is about $8,000 \mathrm{~m}^{3}$, irrigation $22,000 \mathrm{~m}^{3}$ and evapotranspiration $11,000 \mathrm{~m}^{3}$ and the water levels in the ponds are decreasing. It can be seen that the irrigation areas are over-irrigated, indeed, flooded, which results in flushing of the soil underneath the energy grass and the Salix, and this might flush out pollutants. The estimated groundwater inflow during August is considerable and should be controlled by real measurements. A test area constructed similarly to the irrigation areas and equipped with proper bottom liner could give more correct values of the different parts of the water budgets than these rough theoretical calculations and thus better seasonal values of the groundwater inflows.

\section{DISCUSSION}

Landfill owners must have better control today over their landfill than in earlier days. This stands for the material flow into the landfill, transport of chemical substances at the landfill site and its associated unit operations, as well as a water balance for the landfill and its local treatment system. There must be improved contacts between the landfill owner and the decision-maker. Local environmental protection authorities demand good knowledge/control of the water balance of the landfill from both a quantitative and qualitative point view. This makes it necessary to have detailed knowledge of the geohydrological circumstances of the site and its surroundings. A meteorological station should be located on the landfill site, as recommended in Waste Council Directive 199/31/EC on landfilling of waste, in order to get good control on the water balance. A hydro meteorological gauging system should continuously produce data during the construction, operation and post-operation care phases. Water budgets should be calculated on a weekly basis and summarized to monthly and annual values. The system should also be able to analyse extreme rainfall events of short duration, such as convective rainfall events.

The water budget calculation is considered a simple tool for use in communication with the authorities and the decision-makers. It gives good information about design and redesign, as well as measures to avoid unnecessary groundwater inflow to the landfill and the leachate treatment system. Groundwater and surface water inflows can be reduced by the construction of ditches and trenches or the construction of pumping wells to lower the groundwater table and protect the landfill from runoff. The groundwater inflow is a significant part of the water balance at old landfill sites and this unnecessary pollution of clean ground water (on mixing with landfill leachate) can be avoided by a cut trench or 
KALMAR ECO-TECH'03

Bioremediation and Leachate Treatment

KALMAR, SWEDEN, November 25-27, 2003

by pumping. The evaporation from the working face at the landfill and the waste might be hard to estimate because of the difference in water holding capacity between different wastes. It can be assumed that a major part of the precipitation falling over the working faces evaporates from April to the end of September in southern Sweden.

During the last few decades, the modern landfill sites in Europe have transformed from city dumps via sanitary landfills to industrial waste management parks. Recycling and demolition areas are often located at the modern landfill. This has generated new environmental problems from stormwater and emissions to the air. Stormwater runoff from these areas, as well as from primary and secondary roads might be a significant pollutant source, and the runoff cannot be discharged directly to natural waters. This water must be collected and treated, not led directly to receiving waters or infiltrated directly into the ground outside the landfill area. The amount of leachate and stormwater produced at the landfill is largely related to the local climate and geohydrological conditions, but is also affected by the design and location of the landfill and the degree of compaction and composition of the waste. The design of the landfill must follow the EUwaste directive.

\section{ACKNOWLEDGEMENTS}

The Waste Management Companies AB ASSY, KRAB, Kalmar Vatten och Renhållning $\mathrm{AB}$ and the Knowledge Foundation, the Kalmar Research and Development Foundation Graninge Foundation are acknowledged for their sponsorship of the project.

\section{REFERENCES}

[1] Bengtsson, L., Bendz, D., Hogland, W.; Rosquist, H., Åkesson, A., (1994) Water balances for landfills of different age. Journal of Hydrology, No 58. pp 203-2 44.

DOI: https://doi.org/10.1016/0022-1694(94)90054-X

[2] Blight, G.E., Ball, J.M., Blight, J.J., (1991) Moisture distribution in sanitary landfills. In Proceedings of Sardinia Third International Landfill Symposium, Sardinia, Italy.

[3] Campbell, D.J.V., (1983) Understanding water balances in landfills. Waste Management (UK), November.

[4] Falk, J., Gottschalk, L., Hellström, T., Hogland, W., Krasovskaia, I., Niemczynowicz, J. (1983) Hydrologiska undersökningar $i$ Värpinge (Hydrological studies in Värpinge, Sweden), Report 3076, Department of Water Resources Engineering, University of Lund (In Swedish), p. 120.

[5] Guyonnet, D., Didier-Guelorget, B., Provost, G., Feuillet, C., (1998). Accounting for water storageeffects in landfill leachate modelling. Waste Management and Research 16(3):285-295. DOI: https://doi.org/10.1177/0734242X9801600310

[6] Hogland, W., Thörneby, L. Mathiasson, L., 2003 Water Budget for Landfill Leachate Treatment Systems. In: Proceedings of Sardinia 2003 - the Ninth International Conference on the Waste Management and Landfill Symposium, S. Margherita di Pula (Cagliari), Sardinia, Italy, 6-10 October, 2003. (CD) 
KALMAR ECO-TECH'03

Bioremediation and Leachate Treatment

KALMAR, SWEDEN, November 25-27, 2003

[7] Holmes, R., (1980) The water balance method for estimating leachate production from landfill site. Solid Wastes (UK).

[8] Marques, M., Hogland, W., (2003a) Hydrological performance of incineration residues co-disposed with other special waste and MSW co-disposed with sludge in fullscale landfill cells. Waste Management, Elsevier Science Ltd. (in Press), p. 13.

[9] Marques, M., Hogland, W., (2003b) Stormwater runoff and pollutant transport related to the activities carried out in a modern waste management park. Waste Management \& Research (in press), p. 21.

[9] Thörneby, L., (2001 a) Water budgets for natural systems. In proceedings of Kalmar ECO-TECH'O1 - Leachate and waste water treatment with high-tech and natural systems. The $3^{\text {rd }}$ international conference on establishment of cooperation between companies/institutions in the Nordic Countries and the Countries in the Baltic Sea Region, November 26 to 28, Kalmar, Sweden, Hogland, W. and Vysniauskaite, V. (eds), pp. 99-107.

[10] Thörneby, L., (2001 b) Treatment of waste waters with emphasis on reverse osmosis and wetlands. PhD. Thesis, Department of Analytical Chemistry, Lund University, Sweden/Department of Technology, University of Kalmar, Sweden, p. 186.

[11] Uguccioni, M., Zeis, C., 1997. C. 1997. Comparison of two approaches to modelling moisture movement through municipal solid waste. Journal of Environmental Systems 25 (!): 41-63. 